Syntax Idea: p-ISSN: 2684-6853 e-ISSN: 2684-883X

Vol. 3, No. 8, Agustus 2021

\title{
DETERMINAN KETIMPANGAN PENDAPATAN PROVINSI D.I. YOGYAKARTA TAHUN 2012-2020
}

\section{Luluk Miftakhurrohmah Nabila, Lorentino Togar Laut}

Universitas Tidar (UNTIDAR) Magelang Jawa Tengah, Indonesia

Email: luluknabila88@gmail.com, lorentino@untidar.ac.id

\begin{abstract}
Abstrak
Kesejahteraan suatu masyarakat bukan hanya diukur berdasar tingkat besaran pendapatan nasional maupun pendapatan perkapitannya saja tetapi juga dilihat menurut alur pendistribusian pendapatan nasional itu sendiri mengalami ketimpangan atau tersebar secara merata. Bagi negara Indonesia, masalah ketimpangan sulit diatasi karena terdapat perbedaan pendapatan antara masyarakat perkotaan dan perdesaan. Di daerah perkotaan pendapatan yang diperoleh masyarakatnya jauh lebih besar dibanding di perdesaan dikarenakan adanya sokongan dari instansi maupun perusahaan besar sehingga bisa memperoleh upah yang didapat sebanding dengan roda perekonomiannya. Penelitian ini bertujuan mengetahui hubungan-hubungan antar variabel pertumbuhan ekonomi, tingkat pengangguran terbuka dan bantuan sosial terhadap ketimpangan pendapatan di Provinsi Daerah Istimewa Yogyakarta tahun 2012-2020. Penelitian ini menggunakan data sekunder bersumber dari Badan Pusat Statistik (BPS) dan RKPD Provinsi Daerah Istimewa Yogyakarta. Berdasarkan analisis data panel dengan menggunakan bantuan Eviews 10, penggunaan metode pada penelitian ini memakai metode random effect model (REM). Hasil penelitian menyatakan variabel yang berpengaruh terhadap ketimpangan pendapatan merupakan variabel tingkat pengangguran terbuka, variabel bansos tidak berpengaruh positif signifikan dan variabel pertumbuhan ekonomi tidak berpengaruh terhadap ketimpangan pendapatan di Provinsi Daerah Istimewa Yogyakarta tahun 2012 - 2020.
\end{abstract}

Kata Kunci: ketimpangan pendapatan; tingkat pengangguran terbuka; pertumbuhan ekonomi; bantuan sosial

\section{Abstract}

The welfare of a society is not only measured based on the level of national income and per capita income alone but also seen according to the flow of national income distribution itself is inequality or spread evenly. For the Indonesian state, the problem of inequality is difficult to overcome because there is a difference in income between urban and rural communities. In urban areas the income earned by the community is much greater than in rural areas due to the support from agencies and large companies so that they can earn wages that are earned in proportion to the wheels of the economy. This study aims to find out the relationships between economic growth variables, open unemployment rate and social assistance to income inequality in the Province of Yogyakarta Special Region in 2012 - 2020. This study uses secondary data sourced from the Central

$\begin{array}{ll}\text { How to cite: } & \text { Nabila, L. M., \& Laut, L. T. (2021) Determinan Ketimpangan Pendapatan Provinsi D.I. Yogyakarta } \\ & \text { Tahun 2012-2020, Syntax Idea, 3(8), https://doi.org/10.36418/syntax-idea.v6i8.1410 } \\ \text { E-ISSN: } & \text { 2684-883X } \\ \text { Published by: } & \text { Ridwan Institute }\end{array}$


Statistics Agency (BPS) and RKPD of Yogyakarta Special Region Province. Based on the analysis of panel data using the help of Eviews 10, the use of methods in this study using random effect model (REM) method. The results of the study stated that variables that affect income inequality are open unemployment rate variables, bansos variables have no significant positive effect and economic growth variables have no effect on income inequality in the Province of Yogyakarta Special Region in $2012-2020$.

Keywords: income inequality; open unemployment rate; economic growth; social assistance

\section{Pendahuluan}

Ketimpangan merupakan suatu masalah yang sangat kompleks sampai menjadi suatu realita serta isu yang sangat penting untuk segera ditinjau dan diatasi oleh kelompok negara maju ataupun berkembang. Ketimpangan itu sendiri di negara berkembang selama 70 tahun yang lalu telah menjadi topik utama sebagai bahan dasar dalam menentukan arah kebijakan yang telah terjadi. Hal ini dimaksudkan karena terjadinya tendensi bahwa dengan ketentuan-ketentuan pembangunan yang memprioritaskan pertumbuhan ekonomi sudah banyak menimbulkan maraknya tingkat disparitas dalam masyarakat (Cahya Saputri, 2017).

Secara teoritis, tingginya pertumbuhan ekonomi nantinya akan beresiko terhadap perbedaan distribusi pendapatan dalam suatu wilayah. Ketimpangan atau disparitas pendapatan itu erat kaitannya dengan pemerataan dalam hal penyaluran pendapatan yang diberikan oleh masing-masing masyarakat dalam satu daerah atau negara. Apabila ketimpangan pendapatan semakin meningkat maka distribusi pendapatan masyarakat suatu daerah akan mengalami timpang atau ketidakmerataan. Hal itu menimbulkan adanya disekuilibrium (gap) yang semakin melebar antara masyarakat baik dari kelompok kaya dengan pendapatan tinggi maupun kelompok miskin dengan pendapatan rendah (Amri, 2017).

Kuznets merupakan ahli ekonomi pertama yang merumuskan bahwa terdapat keterkaitan diantara ketimpangan distribusi pendapatan terhadap pendapatan perkapita, biasa kita kenal dengan "Hipotesis Kuznets (U-terbalik) (Kuznet, 1955). Hipotesis ini menyatakan hasil pemikirannya bahwa dalam hubungan antara ketimpangan dan pembangunan, yang mana ketika proses pembangunan dimulai, ketimpangan itu akan melebar dan meningkat sampai di titik maksimum, namun ketika memasuki tahap terakhir dari proses pembangunan maka akan terjadi penurunan dalam ketimpangan. Maka dari itu, hubungan tersebut kemudian dinyatakan pada pendapatan perkapita beserta ketimpangan yang berbentuk kurva U-terbalik (Safitri, 2018).

Hasil penelitian ini juga bertentangan dengan penelitian terdahulu yang menemukan bahwa pertumbuhan ekonomi berpengaruh signifikan terhadap ketimpangan pendapatan masyarakat (Nadhifah \& Wibowo, 2021).

Ketimpangan pendapatan terjadi tidak hanya pada daerah perkotaan yang cakupannya besar dan luas. Akan tetapi, di provinsi DI Yogyakarta yang hanya memiliki 5 daerah yang terbagi atas 4 kabupaten dan 1 kota justru merupakan wilayah 
dengan tingkat ketimpangan pendapatan tertinggi di Indonesia. BPS menghitung ketimpangan pendapatan menggunakan indeks gini ratio sebagai tolak ukur. Indeks gini ini dalam perhitungannya menggunakan skala angka yaitu antara 0 - 1. Pemerataan pendapatan dikatakan baik apabila bernilai 0 , yang mana jika koefisien gini semakin besar maka tingkat pemerataan pendapatan menjadi semakin tidak sempurna (Istikharoh et al., 2018). Hal itu menandakan bahwa kesenjangan ekonomi yang terjadi antar kelompok wilayah tersebut menjadi semakin besar (Khoirudin \& Musta'in, 2020). Dalam mengukur rasio ini BPS hanya menghitung melalui jumlah dari pengeluaran konsumsi yang dilakukan oleh masyarakat di tiap tahunnya. Nilai indeks gini di DI Yogyakarta menurut perhitungan BPS lebih tinggi dari pada indeks gini Indonesia yaitu mencapai 0.432 sementara indonesia dengan angka 0.393. Dimana itu menandakan bahwa ketimpangan di Yogyakarta itu melebihi dari kota besar lainnya yang ada di Indonesia ialah DKI Jakarta, Jawa Barat, Jawa Timur, Sumatera Utara, Bali serta Banten.
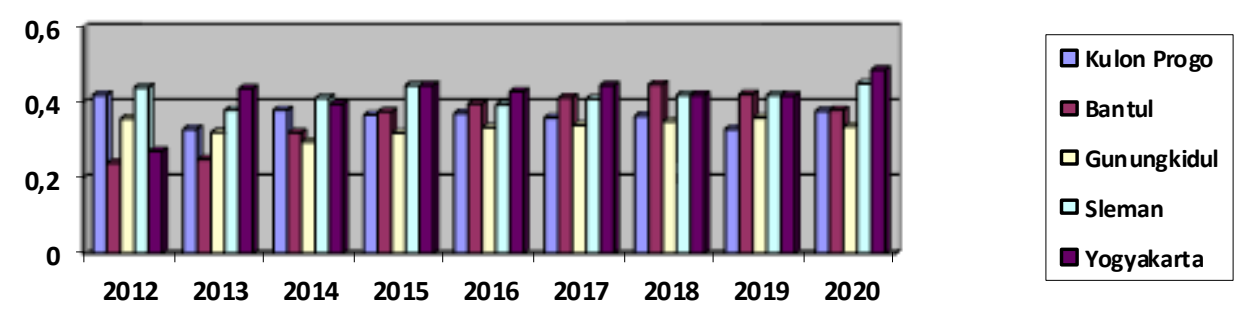

Grafik 1

Perkembangan Gini Ratio Kabupaten/ Kota Provinsi DI Yogyakarta Periode 2012 $-2020$

Sumber : BPS DIY, 2020 (diolah)

Berdasar grafik 1, diketahui di tahun 2012 kabupaten Sleman adalah daerah yang menempati urutan pertama dimana angka indeks gini nya lebih tinggi dari kabupaten/ kota lain yaitu sebesar 0, 44 persen, kemudian kulon progo menyusul dengan berada di urutan kedua dimana angka indeks gini nya mencapai 0,33 . Dan begitu pula sebaliknya daerah yang memiliki angka gini ratio terendah yaitu kabupaten bantul yaitu sebesar 0,24 . Sampai pada tahun 2020 daerah dengan gini ratio tertinggi adalah Kota Yogyakarta dengan angka 0,487 dan di urutan kedua yaitu ada Kabupaten Sleman dengan gini ratio sebesar 0,45. Dan Kabupaten Gunungkidul memiliki gini ratio paling rendah diantara daerah lain yaitu sebesar 0,337. Hal itu berarti menandakan bahwa semakin tinggi ketimpangan pendapatan yang terjadi maka kesejahteraan masyarakat nya menjadi menurun begitu pula sebaliknya apabila ketimpangan pendapatan yang terjadi rendah maka kesejahteraan masyarakatnya semakin membaik atau meningkat.

Pertumbuhan ekonomi merupakan komponen paling pokok dalam suatu proyek pembangunan. Pertumbuhan ekonomi yang tinggi diharapkan dapat meminimalisir terjadinya masalah pembangunan seperti ketimpangan pendapatan. Namun demikian, mutu kehidupan masyarakat belum mampu untuk berubah secara otomatis hanya 
dengan pertumbuhan ekonomi yang meningkat secara cepat. Atau bisa disebut "trickle down effect" yang mana penduduk miskin tidak bisa berharap lebih dari adanya pertumbuhan ekonomi. Sampai apabila tidak terjadi distribusi pendapatan yang merata maka hanya penduduk kaya yang akan menikmati manfaat dari pertumbuhan ekonomi itu. Trade off atau yang biasa disebut perubahan diantara pertumbuhan ekonomi dengan distribusi pendapatan selalu terjadi di berbagai wilayah. Kuznets mengemukakan bahwa seiring berjalannya maka antara distribusi pendapatan dengan pertumbuhan ekonomi dapat meningkat (Sukirno, 2006).
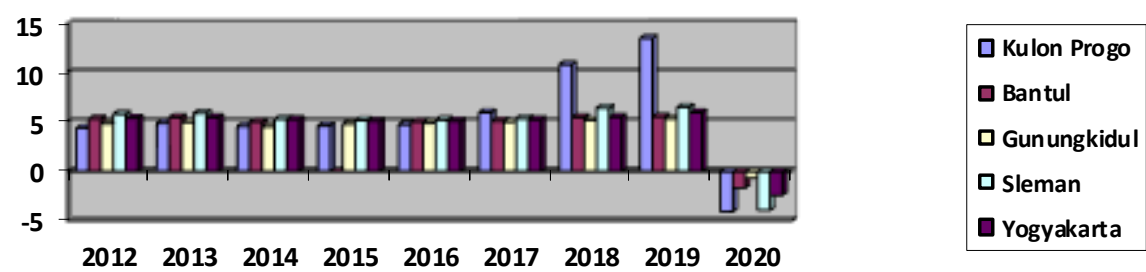

Grafik 2

\section{Perkembangan Pertumbuhan Ekonomi Kabupaten/ Kota Provinsi DI Yogyakarta Periode 2012 - 2020 \\ Sumber : BPS DIY, 2020 (diolah)}

Berdasar grafik 2, diketahui pertumbuhan ekonomi berdasarkan kabupaten/ kota Provinsi DIY tahun 2012-2020 relatif signifikan setiap tahunnya di masing-masing wilayah. Namun di tahun 2020 masing-masing kabupaten/ kota, pertumbuhan ekonominya mengalami kemerosotan sampai pada di titik angka negatif dimana salah satu hal yang paling berdampak bagi pertumbuhan ekonomi yaitu disebabkan karena masalah pandemi covid-19 di Indonesia, terutama yang terjadi di Provinsi DIY belum sepenuhnya teratasi dan hilang di kalangan masyarakat.

Menurut (Kurniawan \& Sugiyanto, 2013) dalam penelitiannya memperoleh hasil yang menggambarkan bahwa pengaruh hubungan positif antara pertumbuhan ekonomi dengan ketimpangan itu terjadi sebab pada daerah yang maju pertumbuhan ekonomi memiliki tingkat yang lebih tinggi daripada daerah di berkembang yang mana akhirnya akan mampu melahirkan serta memperlebar ketimpangan diantara berbagai daerah. Namun hal itu bertentangan dengan (Astuti, 2015) yang dalam penelitiannya menyimpulkan terjadinya keterkaitan antara pertumbuhan ekonomi dan ketimpangan pendapatan tetapi kearah negatif. Semakin meningkatnya Pertumbuhan ekonomi maka akan dapat menurunkan tingkat kesenjangan pendapatan dalam satu wilayah.

Faktor lain yang diduga berpengaruh terhadap ketimpangan pendapatan yakni tingkat pengangguran terbuka. (Efriza, 2014) menyimpulkan apabila tingkat pengangguran terbuka mengalami peningkatan dalam suatu wilayah, maka pendapatan per kapita yangi diterima oleh sekelompok pihak menjadi semakin menurun. Begitu pula sebaliknya, jika tingkat pengangguran menurun, maka akan terjadi peningkatan pendapatan per kapita, yang mana hal itu mungkin dapat menurunkan tingkat ketimpangan pendapatan disuatu wilayah itu juga (Syamsir, A., \& Rahman, 2018). 

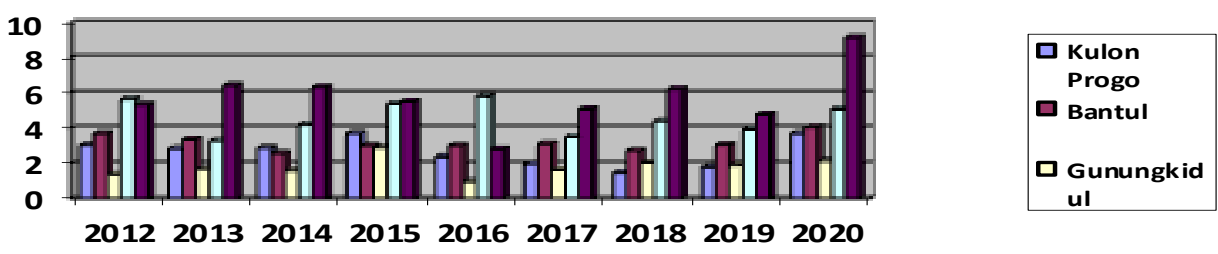

Grafik 3

Perkembangan Tingkat Pengangguran Terbuka Kabupaten/ Kota Provinsi DI Yogyakarta Periode 2012 - 2020

Sumber : BPS DIY, 2020 (diolah)

Grafik 3 diatas menunjukkan bahwa perkembangan TPT tiap kabupaten/kota provinsi DIY dari tahun 2012-2020 cenderung berfluktuatif. Dimana tingkat pengangguran tertinggi selama hampir 9 tahun ditempati Kota Yogyakarta dan paling rendah terletak di kabupaten Gunungkidul. Itu menandakan bahwa terpusatnya 3 kegiatan perekonomian yang relatif tinggi dalam suatu daerah tertentu dapat memacu tingkat pertumbuhan daerah itu menjadi cenderung lebih cepat, sedang daerah lain yang kegiatan perekonomiannya rendah dapat menimbulkan tingginya angka pengangguran serta menjadikan rendah dan menurunnya pendapatan yang akan menyebabkan ketimpangan di daerah itu sendiri (Todaro \& Smith, 2013).

Selanjutnya faktor terduga lain yang dapat mempengaruhi ketimpangan pendapatan yaitu bantuan sosial. Bantuan sosial merupakan salah wujud penyaluran tunjangan atau donasi dari pemerintah daerah berupa uang, barang, atau jasa kepada sekelompok masyarakat maupun keluarga yang sedang dalam kondisi keuangan kurang mampu serta mudah terkena resiko sosial. Maka karenanya, sesuai Peraturan Menteri Dalam Negeri No. 32 Thn. 2011 maka perlu adanya pengeluaran dalam bentuk bantuan sosial yang dapat digunakan untuk mengurangi tingkat kemiskinan yang tinggi dan mendorong kegiatan ekonomi sampai dapat mengurangi atau menahan adanya resiko sosial.

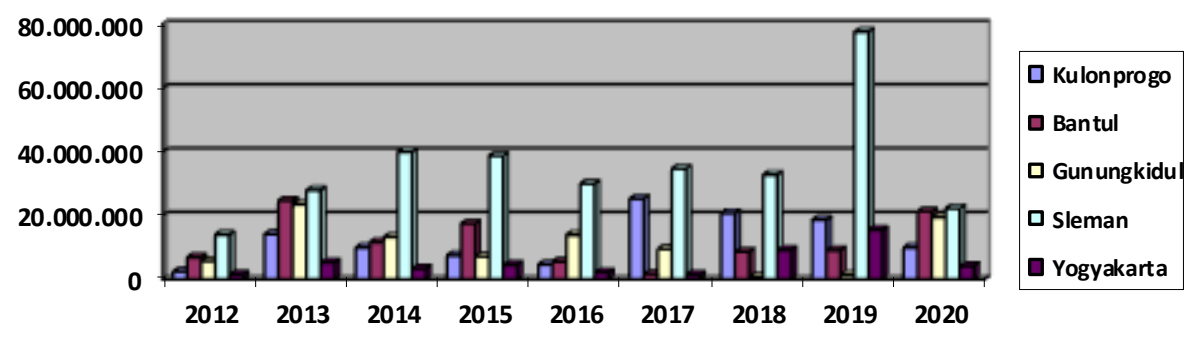

\section{Grafik 4}

Perkembangan Bantuan Sosial Di Kabupaten/ Kota Provinsi DI Yogyakarta

Periode 2012-2020

Sumber : BPS DIY, 2020 (diolah)

Berdasarkan grafik 4 diatas, menunjukkan bahwa tingkat bantuan sosial antar kabupaten/ kota Provinsi DIY dari tahun pertama sampai tahun terakhir berfluktuasi. 
Penyumbang bantuan sosial tertinggi dari tahun 2012 sampai 2020 berada di kabupaten sleman dengan rata-rata Rp. 35.302.805,00. Pada 2012 sampai tahun 2017 Kota Yogyakarta penyumbang bantuan sosial terendah namun, di tahun 2018 sampai 2019 berganti menjadi kabupaten gunungkidul sebagai penyumbang bantuan sosial terendah. Dan 2020 Kota Yogyakarta kembali menjadi penyumbang bantuan sosial terendah dengan nilai sebesar Rp. 1.384.850,00.

Adanya pengalokasian belanja bantuan sosial yang diarahkan sebagaimana mestinya diharapkan bisa mengurangi maupun menurunkan terjadinya kemiskinan dan ketimpangan pendapatan di suatu daerah (Yasni, 2020).

Telah dijelaskan lebih rinci oleh peneliti terdahulu mengenai pengaruh TPT, Pertumbuhan Ekonomi, serta Bantuan Sosial terhadap Ketimpangan Pendapatan. (Todaro \& Smith, 2013) dan (Hassan et al., 2015) melalui penelitiannya di pakistan menyatakan jika saat jangka pendek pertumbuhan ekonomi dan ketimpangan pendapatan mempunyai keterkaitan positif, sedang dalam jangka panjang berhubungan negatif. (Risso \& Carrera, 2012) dan (Amri, 2017) menyatakan bahwa kedua variabel tersebut mempunayi hubungan positif dan signifikan dalam jangka panjang. Penelitian oleh (Sukirno, 2011) dan (Hindun;Soejoto, 2019) mengungkapkan TPT dan ketimpangan pendapatan berpengaruh negatif. Makin banyaknya pengangguran membuat pendapatan upah yang diterima oleh masyarakat golongan rendah akan semakin berkurang sampai dapat mengakibatkan ketimpangan pendapatan yang semakin tinggi. Sementara (Efriza, 2014) menyimpulkan jika diantara kedua variabel pengangguran terbuka dengan ketimpangan pendapatan itu berhubungan positif. Menurut (Habibov \& Fan, 2013) pemberian bantuan sosial belum bisa menangkat taraf hidup masyarakat dari jurang kemiskinan serta tingginya ketimpangan. Berdasarkan penelitian di negara yang memiliki penghasilan rendah dan sedang dalam tahap transisi, membuktikan bahwa pengentasan kemiskinan dan pengurangan ketimpangan tidaklah cukup hanya dengan pemberian bantuan sosial. Hal itu dapat ditimbulkan lantaran manfaat yang diperoleh kelompok miskin sangat kecil dari manfaat yang seharusnya, dilihat berdasar rancangan kebijakannya bantuan sosial bukan untuk mengangkat kemiskinan maupun meminimalisir ketimpangan di negara sedang dalam tahap perpindahan karena itu hanya akan memberatkan pemerintah dalam mencatat masyarakat golongan miskin dan permasalahan tingkat ketimpangan.

Maka dengan ini, penelitian ini akan membahas dan mempelajari lebih lanjut mengenai hubungan-hubungan antar variabel pertumbuhan ekonomi, tingkat pengangguran terbuka dan bantuan sosial terhadap ketimpangan pendapatan di Provinsi Daerah Istimewa Yogyakarta Tahun 2012-2020. Penggunaan variabel-variabel tersebut dimaksudkan supaya kita bisa menggali dan mengkaji lebih dalam mengenai pengaruh faktor-faktor yang menjadi permasalahan ketimpangan pendapatan di Provinsi Daerah Istimewa Yogyakarta sehingga dapat ditemukan solusi maupun kebijakan yang terbaik untuk menanggulangi permasalahan tersebut dikarenakan melalui kebijakan yang diambil akan mempengaruhi pihak pemerintah lokal maupun nasional. 


\section{Metode Penelitian}

Model analisis data memanfaatkan penelitian kuantitatif deskriptif, data yang diperoleh dan diaplikasikan berbentuk angka. Studi empiris dalam penelitian ini memanfaatkan data sekunder dari Badan Pusat Statistik (BPS) serta RKPD Provinsi Daerah Istimewa Yogyakarta. Bentuk data berupa data panel yakni kombinasi antara data time series selama 9 tahun (2012-2020) dengan data cross-section (5 kabupaten/ kota Provinsi DI Yogyakarta).

Metode analisis penelitian ini memakai analisis regresi linear berganda data panel yaitu perpaduan dari data cross section dengan data time series yang saat proses pengerjaannya dibantu menggunakan aplikasi Eviews 10. Menurut (Widarjono, 2018), analisis regresi linear berganda berfungsi sebagai metode untuk mengkaji apakah antar variabel dalam penelitian ini memiliki pengaruh baik parsial maupun simultan. Model dalam penelitian ini yaitu:

$$
\mathrm{KP}_{\mathrm{it}}=\alpha+\beta 1 \mathrm{TPT}_{\mathrm{it}}+\beta 2 \mathrm{PE}_{\mathrm{it}}+\beta 3 \text { BANSOS }_{\mathrm{it}}+\varepsilon_{\mathrm{it}}
$$

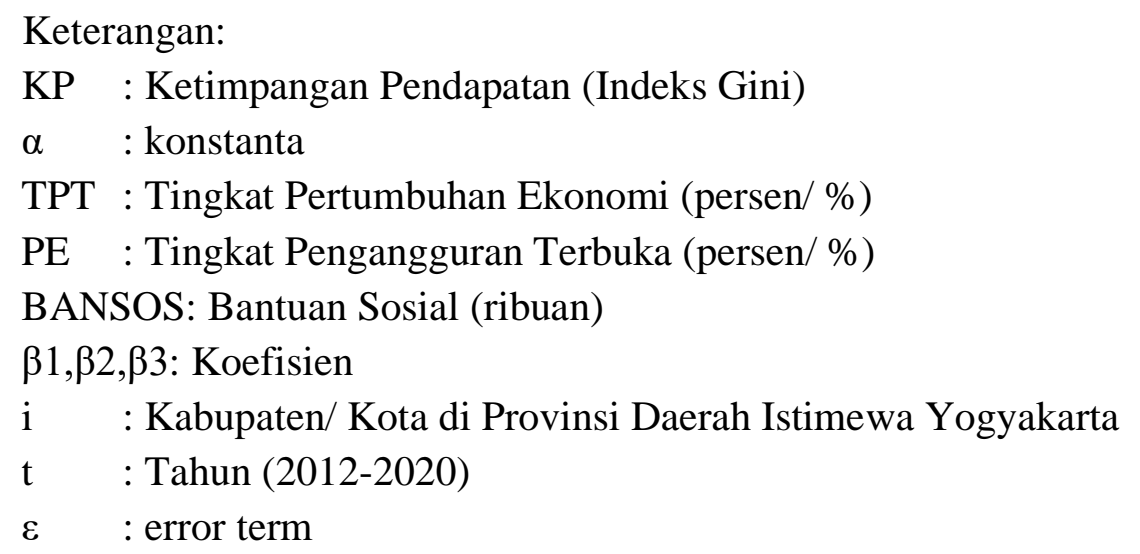

Model diatas bertujuan mengetahui elastisitas diantara variabel terikat terhadap variabel bebas (Abdulah, 2013). Model untuk estimasi dalam data panel dibedakan menjadi 3 macam pendekatan. Pendekatan itu dipilih berdasar model terbaik untuk diapilkasikan yaitu dengan Common Effect, Fixed Effect, atau Random Effect. Sebelum menggunakan 3 model itu diperlukan beberapa langkah-langkah terlebih dahulu untuk mengestimasi model terbaik yaitu dengan menggunakan uji Chow yang bertujuan membuktikan ketika mengestimasi data panel lebih baik menggunakan common effect ataukah fixed effect dengan nilai probability $<\alpha=5 \%(0,05)$. Uji Hausman digunakan untuk menentukan lebih tepat menggunakan model fixed effect model atau random effect, apabila nilai probability $<\alpha=5 \%(0,05)$ berarti penggunaan model terbaik yakni fixed effect. Uji Lagrange Multiplier berguna membuktikan model terbaik dari random effect ataupun ordinary least square saat nilai probability > chi-square.

\section{Hasil dan Pembahasan}

\section{A. Hasil Penelitian}

Berikut pemilihan model paling tepat, yakni melalui uji chow untuk menetapkan model fixed effect atau model common effect. 
Tabel 1

Hasil Chow Test

\begin{tabular}{lcrc}
\hline Effects Test & Statistic & d.f. & Prob. \\
\hline Cross-section F & 1.625023 & $(4,37)$ & 0.1885 \\
\hline Cross-section Chi-square & 7.283033 & 4 & 0.1217 \\
\hline
\end{tabular}

Sumber: Data Diolah, E-views 10

Hasil estimasi chow test tabel 1, nilai probability (p-value) cross-section Chisquare $=0.1217$ dengan tingkat signifikansi error $(\alpha=0.05)$, diperoleh kesimpulan terima Ho dan tolak H1, maka common effect model (CEM) ialah model terbaik.

Berikutnya ialah model Uji Hausman. Uji Hausman untuk menetapkan lebih tepat menggunakan model fixed effect (FEM) atau random effect (REM).

\section{Tabel 2}

\begin{tabular}{lcrc}
\hline & Hasil Hausman Test & \\
\hline & Chi-Sq. & & \\
Test Summary & Statistic & Chi-Sq. d.f. & Prob. \\
\hline Cross-section random & 6.003233 & 3 & 0.1115 \\
\hline
\end{tabular}

Sumber: Data Diolah, E-views 10

Hasil estimasi hausman test tabel 2, diperoleh hasil yakni nilai probability (pvalue) cross-section random $=0.1115$ dengan tingkat signifikansi error $(\alpha=0.05)$ maka terima Ho dan tolak H1, jadi model terbaik untuk digunakan ialah random effect model (REM).

Setelah melalui uji model estimasi, uji chow dan uji hausman diperoleh kesimpulan akhir untuk penggunaan model terbaik dan tepat yakni berupa random effect. Hasil regresi data panel random effect dinyatakan dalam tabel berikut :

Tabel 3

Hasil Regresi Data Panel REM

\begin{tabular}{cc}
\hline Variable & Random Effect Model \\
\hline TPT & 0.0002 \\
\hline PE & 0.6339 \\
\hline BANSOS & 0.2568 \\
\hline C & 0.0000 \\
\hline Rdjusted R-squared & 0.312178 \\
\hline F-statistic & 0.261849 \\
\hline Prob(F-statistic) & 6.202813 \\
\hline Sumber: & 0.001420
\end{tabular}

Sumber: Data Diolah, E-views 10 
Dibawah ini adalah hasil uji estimasi random effect model:

1. Uji F (Simultan)

Hasil uji random effect model menunjukkan nilai f-hitung $=6.202813$ dan nilai probabilitas $=0.001420$ signifikan pada $\alpha=5 \%$, diperoleh kesimpulan yaitu menolak H0 dan menerima H1. Dari pernyataan tersebut bisa ditarik kesimpulan bahwa Tingkat Pengangguran Terbuka, Pertumbuhan Ekonomi, dan Bantuan Sosial secara bersamaan (simultan) berpengaruh terhadap ketimpangan pendapatan.

2. Uji t (Parsial)

Uji t dipergunakan menganalisis adakah pengaruh signifikan secara parsial antara 2 variabel dalam penelitian yaitu variabel bebas dan terikat. Pengujian terfokus pada membandingkan antara $t_{\text {hitung }}$ dengan $t_{\text {tabel }}$ serta membandingkan antara nilai probability terhadap tingkat signfikasi $\alpha=5 \%$.

Hasil pengujian regresi dari tabel 3 diketahui bahwa :

a. Tingkat pengangguran terbuka. Dari uji statistik yang telah dilakukan menujukkan bahwa nilai $t_{\text {hitung }}=4.076782>$ nilai $\mathrm{t}_{\text {tabel }}=1.683$ dan nilai probabilitas $=0.0002<\quad($ taraf nyata $=5 \%)$. Kesimpulannya berupa ada pengaruh positif signifikan dari variabel tingkat pengangguran dan ketimpangan pendapatan DI Yogyakarta. Hasilnya terlihat dalam gambar berikut:

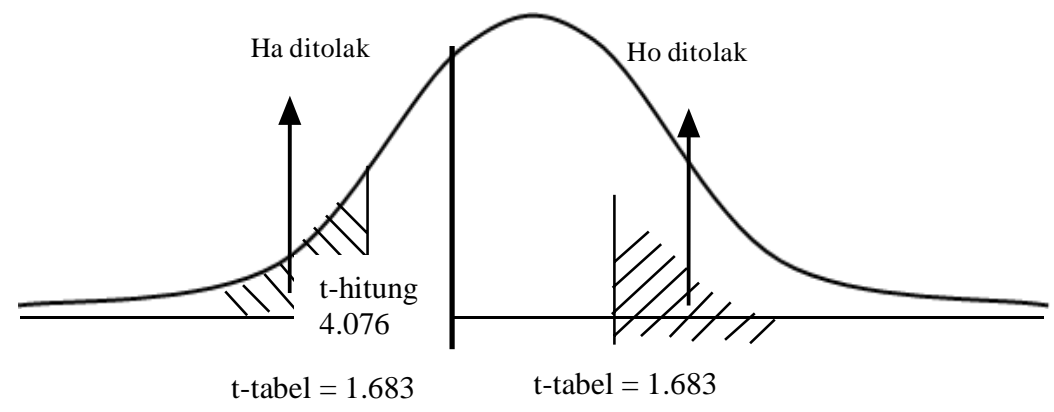

\section{Gambar 1 \\ Hasil Uji t}

b. Pertumbuhan ekonomi. Dari uji statistik yang telah dilakukan menujukkan bahwa nilai $t_{\text {hitung }}=-0.479768<$ nilai $t_{\text {tabel }}=1.683$ dan nilai probabilitas $=$ $0.6339>$ (taraf nyata $=5 \%$ ). Kesimpulannya berupa ada pengaruh negatif tak signifikan dari variabel pertumbuhan ekonomi dan ketimpangan pendapatan DI Yogyakarta. Hasilnya terlihat dalam gambar berikut :

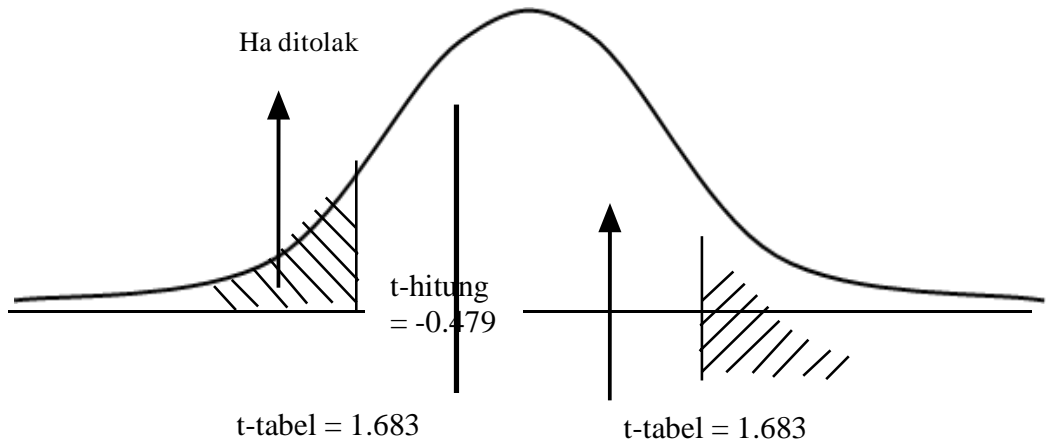




\section{Gambar 2 \\ Hasil Uji t}

c. Bantuan sosial. Dari uji statistik yang telah dilakukan menujukkan bahwa nilai $\mathrm{t}_{\text {hitung }}=1.150026<$ nilai $\mathrm{t}_{\text {tabel }}=1.683$ dan nilai probabilitas $=0.2568>($ taraf nyata $=5 \%$ ). Kesimpulannya berupa ada pengaruh positif tidak signifikan dari variabel pertumbuhan ekonomi dan ketimpangan pendapatan DI Yogyakarta. Hasilnya terlihat dalam gambar berikut :

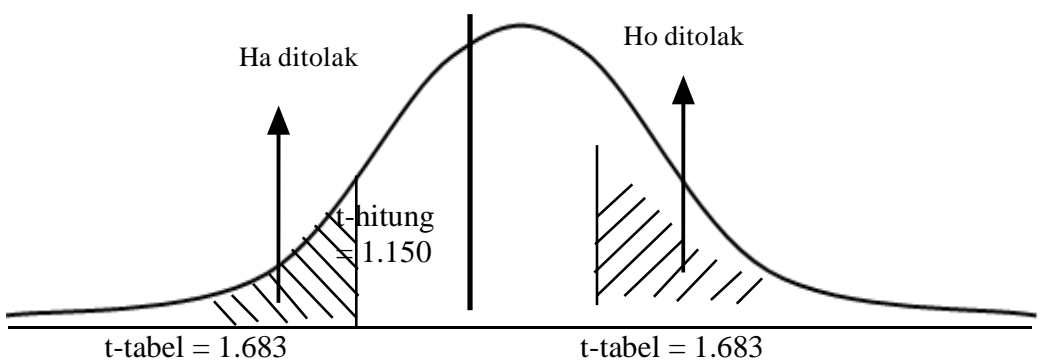

\section{Gambar 3 \\ Hasil Uji $t$}

3. Koefisien Determinasi $\left(\mathrm{R}^{2}\right)$

Hasil uji koefisien determinasi tabel 3 REM, didapatkan nilai R-square $\left(\mathrm{R}^{2}\right)=$ 0.312178 atau sebesar $31,22 \%$. Hal itu menandakan jika 31,22\% ketimpangan pendapatan telah dipengaruhi oleh variabel tingkat pengangguran terbuka, pertumbuhan ekonomi, dan bantuan sosial yang terdapat dalam model penelitian ini. Sedang sisanya $68,78 \%$ dijabarkan melalui variabel lain diluar model dalam penelitian ini.

\section{B. Pembahasan}

Dari pengolahan data sekunder dengan menggunakan E-views 10, diperoleh persamaan regresi panel random effect model seperti berikut :

$$
\begin{gathered}
\mathrm{KP}_{\mathrm{it}}=\alpha+\beta 1 \mathrm{TPT}_{\mathrm{it}}+\beta 2 \mathrm{PE}_{\mathrm{it}}+\beta 3 \mathrm{BANSOS}_{\mathrm{it}}+\varepsilon_{\mathrm{it}} \\
\mathrm{KP}_{\mathrm{it}}=0.315621+0.017614 \mathrm{TPT}_{\mathrm{it}}-0.001185 \mathrm{PE}_{\mathrm{it}}+3.07 \mathrm{E}-10 \mathrm{BANSOS}_{\mathrm{it}}+\varepsilon_{\mathrm{it}}
\end{gathered}
$$

Persamaan diatas akan membahas dan menjelaskan bagaimana pengaruh antara masing-masing variabel terhadap variabel ketimpangan pendapatan yaitu seperti berikut:

\section{Pengaruh Tingkat Pengangguran Terbuka Terhadap Ketimpangan Pendapatan}

Hasil uji regresi membuktikan ketika TPT menghadapi kenaikan sebesar $1 \%$ lalu akan meningkatkan ketimpangan sebanyak $0.017614 \%$. Sedangkan nilai probablitas TPT sebesar 0.0002 yang berarti berpengaruh baik dari segi secara parsial maupun secara simultan terhadap ketimpangan pendapatan. Namun, penelitian (Damarjati, 2010) mengatakan bahwa tidak ada hubungan pengaruh signifikan dari TPT dengan kesenjangan pendapatan yang terjadi di Jawa Tengah 
pada tahun 2004-2008. Penelitian (Masruri, 2016) menjelaskan hal berbanding terbalik bahwa tingkat pengangguran terbuka (TPT) serta kesenjangan pendapatan Jawa Tengah pada 2011-2014 berpengaruh secara signifikan. Hasilnya menunjukkan bahwa Pengangguran itu bisa mengganggu penurunan ketimpangan di Jawa Tengah karena penduduk-penduduk yang menganggur tidak dapat menghasilkan produk-produk ekonomi. Situasi itu diperjelas pula bahwasannya urbanisasi menuju daerah yang lebih maju perekonomiannya menyebebkan munculnya pengangguran terbuka sampai banyak kota besar terbebani oleh angkatan kerja yang semakin banyak namun lapangan kerjanya terbatas dan memunculkan ketimpangan yang semakin besar.

\section{Pengaruh Pertumbuhan Ekonomi Terhadap Ketimpangan Pendapatan}

Hasil uji regresi membuktikan bahwa pertumbuhan ekonomi tidak mempengaruhi ketimpangan pendapatan Provinsi D.I. Yogyakarta tahun 20122020. Pertumbuhan Ekonomi memiliki koefisien -0.001185 dengan nilai probabilitas 0.6339 artinya setiap terjadi kenaikan $1 \%$ dari pertumbuhan ekonomi tidak akan mampu merendahkan ketimpangan pendapatan sebanyak $0.001185 \%$. Hasil uji analisis ini sama dengan penelitian (Permana, 2016) yang menyimpulkan jika diantara ketimpangan pendapatan dan pertumbuhan ekonomi ada pengaruh negatif tidak signifikan. Itu juga sejalan dengan penelitian (Ogus Binatli, 2012) yang menjelaskan bahwa pertumbuhan ekonomi tidak berhubungan dengan ketimpangan pendapatan. Hal itu disebabkan karena pengaruh data sebelumnya yang hanya sampai pada tahun tertentu. Perbandingan 2 periode tersebut mempunyai hubungan yang berbeda diantara kedua variabel tersebut yang mana pertumbuhan ekonomi itu memiliki efek lebih besar dari pada ketimpangan pendapatan.

Hasil ini berbanding terbalik dengan penelitian (Masruri, 2016) yang mengatakan pertumbuhan ekonomi berpengaruh terhadap ketimpangan ekonomi yang mana jika pertumbuhan ekonomi mengalami naik turun justru membuat ketimpangan ikut meningkat. Tingginya ketimpangan pendapatan diiringi dengan trend yang menurun dimana penurunan itu tidak diikuti dengan pertumbuhan yang meningkat maka hasilnya pertumbuhan ekonomi akan berpengaruh signifikan akan tetapi pada tingkat level terjadi penghambatan sampai ketimpangan mengalami penurunan secara non maksimal dan selaras dengan teori neo marxist yang menerangkan pertumbuhan ekonomi akhirnya menjadi satu faktor yang menyebabkan jurang ketimpangan kalangan berkecukupan serta berkekurangan meluas lalu kian melonjak.

\section{Pengaruh Bantuan Sosial Terhadap Pertumbuhan Ekonomi}

Hasil uji regresi menunjukkan bantuan sosial tidak memberikan pengaruh terhadap ketimpangan pendapatan. Bantuan Sosial memiliki nilai koefisien 3.07E10 dengan nilai probabilitas 0.2568 yang berarti setiap terjadi kenaikan $1 \%$ bantuan sosial akan meningkatkan ketimpangan pendapatan sebesar 3.07E-10\%. Hasil penelitian itu seperti penelitian yang dilakukan (Yasni, 2020) yang 
menyimpulkan bahwa belanja bantuan sosial mempunyai pengaruh tidak signifikan terhadap ketimpangan pendapatan Nasional. Terjadi peningkatan pada masyarakat yang berpendapatan rendah saja belum tentu akan menurunkan ketimpangan pendapatan itu. Akita et al (1999) dalam penelitiannya mendukung pernyataan diatas yang mengatakan bahwa diantara pengeluaran rumah tangga/ pendapatan rumah tangga dengan ketimpangan pendapatan tidak ada pengaruh signifikan. Riau adalah provinsi yang pendapatannya tertinggi ketiga di indonesia namun ketimpangannya kecil. Sebaliknya, nusa tenggara barat termasuk provinsi yang berpendapatan rendah dan ketimpangannya masuk kategori tinggi. Hal itu berarti bahwa dengan pendapatan yang tersu bertambah tidak selalu berpengaruh terhadap berkurangnya ketimpangan.

\section{Kesimpulan}

Dapat diambil kesimpulan dari hasil dan pembahasan mengenai Determinan Ketimpangan Pendapatan Provinsi D.I.Yogyakarta Tahun 2012-2020 yaitu: Tingkat pengangguran terbuka mempengaruhi ketimpangan pendapatan secara signifikan di Provinsi DI Yogyakarta tahun 2012-2020. Itu menandakan setiap peningkatan dalam tingkat pengangguran terbuka dapat mengakibatkan terjadinya ketimpangan pendapatan begitu pula sebaliknya. Namun, pengaruh dari tingkat pengangguran terbuka signifikan. Pertumbuhan ekonomi tak mempengaruhi ketimpangan pendapatan di Provinsi DI Yogyakarta tahun 2012-2020. Itu menandakan setiap peningkatan dalam pertumbuhan ekonomi tidak akan menyebabkan ketimpangan pendapatan begitu pula sebaliknya. Bantuan sosial mempengaruhi ketimpangan pendapatan secara tidak signifikan di Provinsi DI Yogyakarta tahun 2012-2020. Itu menandakan setiap peningkatan dalam bantuan sosial akan menyebabkan terjadinya ketimpangan pendapatan begitu pula sebaliknya. Namun, pengaruh dari bantuan sosial tidak signifikan. Ketimpangan pendapatan di Provinsi DI Yogyakarta tahun 2012-2020 secara bersama-sama dipengaruhi oleh Tingkat pengangguran terbuka, pertumbuhan ekonomi, dan bantuan sosial.

Rekomendasi dari hasil dan pembahasan mengenai Determinan Ketimpangan Pendapatan Provinsi D.I.Yogyakarta Tahun 2012-2020 yaitu: Dari pihak Pemerintah Provinsi Daerah Istimewa Yogyakarta diperlukan adanya suatu bentuk kepedulian seperti perluasan lapangan pekerjaan bagi masyarakat untuk memperoleh kesempatan kerja yang lebih baik agar tingkat pengangguran terbuka dapat berkurang sedikit demi sedikit sampai ketimpangan pendapatan juga akan mengalami penurunan. Perlu adanya evaluasi lebih dalam mengenai anggaran dan penyaluran belanja bantuan sosial yang diberikan oleh Pemerintah supaya hal itu nantinya tersalurkan sesuai sasarannya sampai diharapkan dengan hal itu bisa sedikit demi sedikit mampu mengurangi ketimpangan pendapatan yang ada. Pemerintah Daerah Istimewa Yogyakarta diharapkan mampu mengambil langkah kebijakan yang tepat guna baik dari segi perekonomian ataupun non perekonomian supaya ketimpangan menurun dan distribusi pendapatan dapat terlaksana secara merata. 


\section{BIBLIOGRAFI}

Abdulah, R. (2013). Faktor-Faktor Yang Memengaruhi Ketimpangan Pendapatan Di Jawa Tengah. JEJAK: Jurnal Ekonomi Dan Kebijakan, 6(1), 42-53. Google Scholar

Amri, K. (2017). Analisis Pertumbuhan Ekonomi dan Ketimpangan Pendapatan : Panel Data 8 Provinsi di Sumatera. Jurnal Ekonomi Dan Manajemen Teknologi (EMT), 1(1), 1-11. Google Scholar

Astuti, R. D. (2015). Analisis Determinan Ketimpangan Distribusi Pendapatan di Daerah Istimewa Yogyakarta Periode 2005-2013. Tirtayasa Ekonomika, 15(1), 1730. Google Scholar

Cahya Saputri, R. G. (2017). Pengaruh Produktivitas Sektoral Dan Laju Pdrb Terhadap Tingkat Ketimpangan Pendapatan Di Jawa Tengah Pada Tahun 2006 - 2015. Jurnal REP (Riset Ekonomi Pembangunan), 2(1), 103-112. Google Scholar

Damarjati, A. G. (2010). Analisis faktor-faktor yang mempengaruhi kesenjangan pendapatan di propinsi jawa tengah. Google Scholar

Efriza, U. (2014). Analisis Kesenjangan Pendapatan Antar Kabupaten / Kota Di Provinsi Jawa Timur Di Era Desentralisasi Fiskal. Jurnal Universitas Brawijaya Malang. Google Scholar

Habibov, N. N., \& Fan, L. (2013). Social assistance and the challenges of poverty and inequality in Azerbaijan, a low-income country in transition. Journal of Sociology and Social Welfare, 33(1), 203-226. Google Scholar

Hassan, S. A., Zaman, K., \& Gul, S. (2015). The Relationship between GrowthInequality-Poverty Triangle and Environmental Degradation: Unveiling the Reality. Arab Economic and Business Journal, 10(1), 57-71. Google Scholar

Hindun;Soejoto, A. (2019). Pengaruh Pendidikan , Pengangguran , dan Kemiskinan terhadap Ketimpangan Pendapatan di Indonesia. Jurnal Ekonomi Bisnis Dan Kewirausahaan, 8(3), 250-265. Google Scholar

Istikharoh, Prijanto, W. J., \& Destiningsih, R. (2018). Analisis Pengaruh Tingkat Pendidikan , Upah Minimum Dan Tingkat Pengangguran Terhadap Ketimpangan Pendapatan Di Daerah Istimewa Yogyakarta Tahun 2008 -. Directory Journal of Economic, 2(1). Google Scholar

Khoirudin, R., \& Musta'in, J. L. (2020). Analisis Determinan Ketimpangan Pendapatan di Daerah Istimewa Yogyakarta. Tirtayasa Ekonomika, 15(1), 17-30. Google Scholar

Kurniawan, B. R. A., \& Sugiyanto, F. (2013). Pengaruh Pertumbuhan Ekonomi, Share 
Sektor Industri Dan Pertanian Serta Tingkat Jumlah Orang Yang Bekerja Terhadap Ketimpangan Wilayah Antar Kabupaten/Kota Di Jawa Tengah Tahun 2002-2010. Diponegoro Journal of Economics, 2(1), 1-14. Google Scholar

Kuznet, S. (1955). Growth and Income Inequality. The American Economic Review. Google Scholar

Masruri. (2016). Analisis Pengaruh Pertumbuhan Ekonomi, Ipm, Tpak Dan Pengangguran Terbuka Terhadap Ketimpangan Pendapatan Antar Daerah Di Provinsi Jawa Tengah Tahun 2011-2014. Jurnal Ilmiah, 1-13. Google Scholar

Nadhifah, T., \& Wibowo, M. G. (2021). Determinan Ketimpangan Pendapatan Masyarakat Di Daerah Istimewa Yogyakarta. Jurnal Ekonomi Dan Bisnis, 24(1), 39-52. Google Scholar

Ogus Binatli, A. (2012). Growth and Income Inequality: A Comparative Analysis. Economics Research International, 2012, 1-7. Google Scholar

Permana, R. (2016). Faktor-Faktor yang Mempengaruhi Tingkat Kemiskinan di Provinsi Kalimantan Timur. Forum Ekonomi: Jurnal Ekonomi, Manajemen Dan Akuntansi, 18(2), 111-129. Google Scholar

Risso, W. A., \& Carrera, E. J. S. (2012). Inequality and economic growth in China. Journal of Chinese Economic and Foreign Trade Studies, 5(2), 80-90. Google Scholar

Safitri, D. (2018). Analisis Ketimpangan Dan Dispersi Pertumbuhan Di Provinsi Jawa Tengah Tahun 2001-2018. Google Scholar

Sukirno, S. (2006). Teori Pengantar Ekonomi Makro. In Jakarta. Google Scholar

Sukirno, S. (2011). Teori Pengantar Makroekonomi. Rajawali Press. Google Scholar

Syamsir, A., \& Rahman, A. (2018). Menelusuri Ketimpangan Distribusi Pendapatan Kabupaten dan Kota. EcceS (Economics, Social, and Development Studies), 5(1), 22. Google Scholar

Todaro, M. P., \& Smith, S. C. (2013). Pembangunan ekonomi edisi kesembilan. In Erlangga.

Widarjono, A. (2018). Ekonometrika: Pengantar dan Aplikasinya. In Jakarta: Ekonosia.

Yasni, R. (2020). Peran Belanja Modal Dan Belanja Bantuan Sosial Pemerintah Daerah Terhadap Ketimpangan Pendapatan Di Indonesia. Substansi: Sumber Artikel Akuntansi Auditing Dan Keuangan Vokasi, 4(1), 39-63. Google Scholar

\section{Copyright holder:}


Luluk Miftakhurrohmah Nabila, Lorentino Togar Laut

Luluk Miftakhurrohmah Nabila, Lorentino Togar Laut (2021)

First publication right:

Syntax Idea

This article is licensed under:

(c) (i) (2) 